\title{
LOCAL NEXUS IN MERGER CONTROL REGIMES
}

\author{
Daniela Lukáčová \\ Antimonopoly Office of the Slovak Republic ${ }^{2}$
}

\begin{abstract}
Merger control is one of the competition law tools. While competition authorities in EU act primarily on the basis of national legislation, European Commission controls mergers with EU dimension. The jurisdictional tests relate only to the economic size of the parties and do not depend on the market shares of the parties or substantive impact of the transaction, or on whether the concentration will have any effects within the state. Globalization increases the number of multijurisdictional mergers that are subject to control of several competition authorities within or outside the EU. Differences in merger control proceedings in such cases with regard to the timeframe, or the result of the proceeding, could have a negative impact on the economy in another country. Parties to the concentration could decide to neglect the merger notification due to the timeframe, or complications connected with approving of multijurisdictional merger in other countries with jurisdiction. Therefore, the national authorities' effort to set in their legislation turnover criteria with local nexus could help to control concentrations with potential effect on competition in their country.
\end{abstract}

Key words: Local nexus, merger control, multijurisdictional mergers, globalization

\section{INTRODUCTION}

Merger control is one of the competition law enforcement tools. Competition authorities in EU act primarily on the basis of national legislation. European Commission controls mergers with EU dimension, a concept which depends on the respective turnovers of the undertakings concerned. ${ }^{3}$ While definition of a merger transaction seeks to identify those transactions that result in a more durable combination of previously independent businesses or assets, notification thresholds are used to identify transactions that have a sufficiently material nexus to a given jurisdiction. The jurisdictional tests relate only to the economic size of the parties and do not depend on the market shares of the parties or substantive impact of the transaction, nor on whether the concentration will have any effects within the state.

Globalization increases the number of multijurisdictional mergers that are subject to control of several competition authorities within the European area but also outside it. Differences in merger control proceedings in case of global mergers with regard to the timeframe, or the result of the proceeding, could have a negative impact on the economy in another country. In such cases par-

1 Tento projekt vznikol za podpory Agentúry na podporu výskumu a vývoja, grantu č. APVV-0158- 2 (Efektívnost právnej úpravy ochrany hospodárskej sútaže v kontexte jej aplikácie v praxi) a Právnickej fakulty Univerzity Komenského v Bratislave. This paper was supported by the Grant APVV-0158- 2 The Effectiveness of Competition Law in the Context of its Application in Praxis.

2 All views expressed in this paper are strictly personal and should not be construed as reflecting the opinion of the Antimonopoly Office of the Slovak Republic.

3 ROSE, V. - ROTH, P.: European Community Law of Competition (Bellamy \& Child). Oxford: Oxford University Press, 2009, p. 660. 
ties to the concentration could decide to neglect the merger notification due to the timeframe, or complications connected with approving of global merger in countries with jurisdiction. Therefore, the national authorities' effort to set in their legislation turnover criteria with local nexus could help to aim control on concentrations with potential effect on competition in their country, in respect of which a reasonable likelihood of outcomes can be expected that conflict with the policy goals of a competition law regime.

\section{LOCAL NEXUS}

In establishing merger notification thresholds, each jurisdiction should seek to screen out transactions that are unlikely to result in appreciable competitive effects within its territory. Requiring merger notification as to such transactions imposes unnecessary transaction costs and commitment of competition agency resources without any corresponding enforcement benefit.

Merger notification thresholds should therefore incorporate appropriate standards of materiality as to the level of "local nexus" required, such as material sales or assets levels within the territory of the jurisdiction concerned. The "local nexus" thresholds should also be confined to the relevant entities or businesses that will be combined in the proposed transaction. In particular, the relevant sales and/or assets of the acquired party should generally be limited to the sales and/or assets of the business(es) being acquired.

This "local nexus" approach does not preclude the use of ancillary thresholds based on worldwide activities of the parties as an additional prerequisite, but worldwide revenues or assets should not be sufficient to trigger a merger notification requirement in the absence of a local nexus (e.g. revenues or assets in the jurisdiction concerned) exceeding appropriate materiality thresholds. ${ }^{4}$

\subsection{Slovak Republic legislation reform}

Merger control in Slovakia falls within the scope of the Antimonopoly Office of the Slovak Republic (hereinafter "AMO", "Office"), which is an independent central body of state administration of the Slovak Republic for the protection of competition. The competition legislation is to a great extent in line with the European law.

The AMO made substantive changes in relation to local nexus issues in 2011. Criteria for determining whether the concentration is subject to control by the Office were adjusted in new manner. These changes were adopted by amendment to the Act No. 136/2001 on Protection of Competition (hereinafter "Act on Protection of Competition"). The amendment newly setting the notification criteria regarded the relation to the domestic market, so called local nexus.

This process was prepared in order to arrange effective merger control system without imposing substantial cost on competition authority and merging parties.

Mergers meeting the turnover criteria set by the Article 10, par. 1, letter a) or b) Act on Protection of Competition are subject to ex ante mandatory notification - they fall under the control of the AMO.

$4 \quad$ ICN Recommended Practices For Merger Notification Procedures, p. 1. 
A concentration shall be subject to control by the Office if:

a) the combined global turnover of the parties to the concentration is at least EUR 46,000,000 for the closed accounting period preceding the establishment of the concentration and at least two of the parties to the concentration attain a turnover of at least EUR 14,000,000 each in the Slovak Republic for the closed accounting period preceding the establishment of the concentration; or

b) at least one of the parties to the concentration attains a total turnover of at least EUR 19,000,000 in the Slovak Republic for the closed accounting period preceding the establishment of the concentration and at least one other party to the concentration attains a total global turnover of at least EUR 46,000,000 for the closed accounting period preceding the establishment of the concentration.

\section{Chart 1: Legislation before reform}

A concentration shall be subject to control by the Office if:

a) the combined aggregate turnover of the parties to the concentration is at least EUR 46,000,000 attained for the accounting period preceding the establishment of the concentration in the Slovak Republic and at least two of the parties to the concentration attain a turnover of at least EUR 14,000,000 each in the Slovak Republic for the accounting period preceding the establishment of the concentration; or

b) combined turnover attained for the accounting period preceding the establishment of the concentration in the Slovak Republic

1. if it is a matter of concentration pursuant to the article 9, par. 1, letter a) at least by one of the parties to the concentration is EUR 14,000,000 and simultaneously the global combined turnover for the accounting period preceding the establishment of the concentration attained by another party to the concentration is at least EUR 46,000,000,

2. if it is a matter of concentration pursuant to the article 9, par. 1, letter b) by at least one party to the concentration that is being acquired or its part is being acquired is at least EUR 14,000,000 and simultaneously the global combined turnover for the accounting period preceding the establishment of the concentration attained by whichever other party to the concentration is at least EUR 46,000,000,

3. if it is a matter of concentration pursuant to the article 9, par. 5 at least by one of the parties to the concentration creating jointly controlled enterprise is at least EUR 14,000,000 and simultaneously the global combined turnover for the accounting period preceding the establishment of the concentration attained by another party to the concentration is at least EUR 46,000,000.

\section{Chart 2: Legislation after reform}

The criteria determining whether a concentration is subject to control by the Office, were redefined with the goal to eliminate the mandatory notification of concentrations in cases which do not have any impact on markets in Slovakia but had to be notified due to the global turnover of undertakings concerned. Subject to merger review in the previous wording of the Act were also transactions, where the acquired company had not significant activities in Slovakia. Thus the AMO reviewed the amount of mergers without, or with minimal impact on the market in the Slovak Republic. Such mergers were reviewed due to the fact that the acquirer reached the set turnover threshold in the Slovak Republic and the acquired reached the set global turnover threshold. Before new legislation came into force, the AMO dealt with ca. 23 cases in 2011, around $25 \%$ were cases without any potential impact on competition in the Slovak Republic. 
2011 reform, including the process of setting thresholds, was based on the ICN principles, 2005 OECD Council Recommendation, examination of individual sectors in economy in Slovakia, the size of these industries and whole economy, the amount of sales achieved by companies in individual sectors, benchmark based on past experience as well as comparison with the notification criteria in countries with a GDP similar to that of the Slovak Republic. Also the results of the public consultation were taken into account in the process of adopting new legislation.

The criteria for mandatory notifications in cases of acquisitions have changed significantly. According to article 10, par. 1 point a) both the combined aggregate turnover of the undertakings concerned and the aggregate turnover of at least two of the undertakings concerned are linked to the turnover attained in the Slovak Republic and according to article 10, par. 1 point b) the entity which must attain the aggregate turnover in the Slovak Republic is determined according to the type of merger and the other undertaking concerned must attain worldwide aggregate turnover in a given amount.

Above shows that pursuant to the new wording the acquired company must attain the turnover in the Slovak Republic. The AMO assumption was that this could result in elimination of obligatory notification of mergers in which the acquired company had met only the criterion of worldwide turnover and had no significant participation in competition in the domestic market.

The AMO concluded that thresholds should be better targeted to result in a greater number of notifications of mergers with domestic reach without increasing the total number of notifications.

The goal of the notification criteria reform was to allow the Office to focus only on the most serious economic combinations of undertakings and to reduce the number of obligatory notified concentrations that even potentially could not have negative impact consisting in substantial lessening of competition in markets involving the Slovak Republic.

As a result of reforms, the number of notifications remained constant and almost all these cases had the local nexus in SR.

The AMO also complemented local nexus issue in 2011 and 2014 Amendments to the Act on Protection of Competition by other changes to determine costs and burdens of a merger control review system, such as a two phase process merger review, or short form of notification system.

\subsection{Unsolved problems}

Even though the criteria were changed with intention to set them at a level calculated to minimize the number of transactions that must be notified (that are unlikely to raise competitive concerns), without allowing transactions that raise concerns to fall outside the notification requirement, some questions remain open and unsolved.

In fact there is one type of mergers, within which, even under current notification system, we can find cases without any local nexus. These are cases notifiable under current notification system such as cases of joint ventures created by at least one parent company with activities in Slovakia (turnover threshold met in Slovakia) and by the other parent company, which fulfilled global turnover threshold and at the same time their JV is active/will be active solely abroad. The AMO dealt with approximately 4 such cases in 2012 - 2016.

\section{Construction companies' case}

Two construction companies created joint venture for the rental of construction equipment and maintenance work in Nordic countries. One of these parent companies was active in Slovakia, but the other 
one was not, even this JV was not. But this concentration fell under AMO review according to Article 10, par. 1, letter b) 3 of the Act on Protection of Competition.

\section{Publisher case}

Two Swiss companies publishing newspapers and magazines created new joint venture for magazine publishing which had to be active only in France. These companies had also the joint venture in the Slovak Republic (turnover thresholds met in Slovakia), and they also fulfilled global turnover threshold, but the activity of JV was aimed at other local market. It fell under AMO review according to the same Article as the case above.

\section{Airport Chile case}

One airport services provider and one construction company created joint venture for providing airport reconstruction and airport operation in Chile. The construction company provided construction services with significant turnover also in Slovakia (Slovak turnover threshold), the other parent company fulfilled global turnover threshold and the activity of JV was solely outside the Slovak Republic.

\section{Multifunctional objects/business centre case}

One construction company, specialized in construction of business centres, and one financial institution, both Finnish companies, created joint venture for construction and operation of business centre in Nordic countries. Construction Company fulfilled Slovak turnover threshold, financial institution fulfilled global turnover threshold and again, the JV was intended to operate solely outside Slovakia. Both of these cases fell under AMO review according to the same Article as the case above.

\section{Chart 3: JV cases}

This means that Act on Protection of Competition can apply to concentrations outside the Slovakia and regardless of the nationalities of the parties. As the control of concentrations in Slovakia is to a great extend modelled after the EU system with some procedural divergences, similar situation occurs also within the EU dimension. ${ }^{5}$

\section{CONCLUSION}

Above mentioned demonstrates that merger notification system revision is important in order to seek improvement, to achieve effective objective and convergence towards recognised best practices. Current setting namely contains some gaps. Above cases could serve as an example that sometimes notification criteria, upon which the local nexus is set, are insufficient.

It is possible to use some instruments that could help to make proceeding more effective in above JV cases under current legislation. Parties can use pre-notification contacts; short form CO with reduced information requirements, and the competition authority could issue decision in $1^{\text {st }}$ phase proceeding without market investigation and detailed reasoning decision.

One of the possible solutions in future is to exclude the creation of joint ventures that will operate outside the Slovakia and have no impact on markets in Slovakia from the scope of AMO in the next Amendment to the Act on Protection of Competition. Such approach is also part of proposal

5 High profile Phase II cases between non-European companies include Case M.619 Gencor/Lonrho, OJ 1997 L11/30, Case Boeing/McDonnell Douglas, OJ 1997L336/16, Case M.1069 Worldcom/MCI II OJ 1999 L116/1, Case M.2220 General Electric/Honeywell, OJ 2004 L48/1, Case M.3216 Oracle/PeopleSoft, OJ 2005 L218/6. 
of the 2014 White Paper Towards more effective EU merger control ${ }^{6}$, which covers these cases at the European level.

\section{Bibliography:}

ROSE, V. - ROTH, P.: European Community Law of Competition (Bellamy \& Child). 6th edition. Oxford: Oxford University Press, 2008, ISBN 978-0-19-928644-7.

ICN Merger working group: Recommended Practices For Merger Notification Procedures http://www.internationalcompetitionnetwork.org/working-groups/current/merger/notification-procedures.aspx

OECD, Recommendation of the Council on Merger Review C(2005)34, 23.3.2005 http://acts.oecd.org/Instruments/ ShowInstrumentView.aspx?InstrumentID=195\&InstrumentPID=191\&Lang=en\&Book=False

OECD, Background paper by Secretariat: Local nexus and jurisdictional thresholds in merger control, DAF/COMP/ WP3(2016)4, 10.3.2016.

EUROPEAN COMMISSION, White Paper Towards more effective EU merger control, COM(2014) 449.

\section{Contact information:}

Mgr. Daniela Lukáčová

daniela.lukacova@antimon.gov.sk

Antimonopoly Office of the Slovak Republic

Drieňová 24

82103

Slovak Republic 